\title{
A declarative decision support framework for supply chain problems
}

\author{
Paweł Sitek \\ Kielce University of Technology \\ Al. 1000-lecia PP 7,25-314 Kielce, Poland, \\ Institute of Management and Control Systems \\ e-mail:sitek@tu.kielce.pl
}

\begin{abstract}
The author presents a novel declarative approach to modeling, solving and decision support for supply chain problems as a declarative decision support framework. The proposed framework makes it possible to ask different types of questions (general, specific, logical etc.). The implementation of the framework was performed in the CLP (Constraint Logic Programming) environment.

To increase the efficiency of the framework, particularly in the area of optimization made its integration with MP (Mathematical Programming) environment. The paper also presents the implementation of illustrative model, using the proposed framework. In addition, an efficiency analysis of the presented solution in relation to the application of mathematical programming have been conducted.
\end{abstract}

\section{INTRODUCTION}

$\mathrm{T}$ HE ssupply chain (SC) is commonly seen as a collection of various types of companies (raw materials, production, trade, logistics, transport, etc.) working together to improve the flow of products, information and finance. As the words in the term indicate, the supply chain is a combination of its individual links in the process of supplying products (material/products and services) to the market.

There is a considerable literature on the supply chain management problems [1,2].

The major difficulties that appear in supply chain management (SCM) include large amount of information and multiple constraints relating to each participant in the management process. These participants share many of those constraints and information items [3], which further complicates the management. The constraints have various characters and structures. The most common are the constraints related to resources, time, finance, transportation, environment, business, law and safety. They can be linear constraints, non-linear, binary integer and logical. Managers/Decision makers are typically interested in feasibility and/or optimality of the decisions they make in the environment with many constraints. The most natural way to support the decision makers is to enable them to ask questions and obtain answers within acceptable time.

Good environments for the modeling of constraints, questions and logical conditions include declarative environments, CLP (Constraint Logic Programming) in particular.

Our motivation was to develop a framework for the modeling and decision support for supply chain management problems. The use of this framework would help obtain quick answers to key questions (Is it possible...?, What If...?, What is the minimum/maximum..? ) asked by managers/decision makers.

This paper proposes the concept of a declarative decision support framework for supply chain problems and presents its implementation in the CLP environment. The illustrative example shows the potential of the framework.

The remainder of the article is organized as follows. Section 2 presents problem statement, research methodology, contribution etc. The concept and implementation aspects of a declarative decision support framework are provided in Section 3. Computational examples, tests of the implementation platform and discussion are presented in Section 4. Possible extensions of the proposed approach as well as the conclusions are included in Section 5. .

\section{PROBLEM STATEMENT AND METHODOLOGY}

Most of the SC decision and optimization problems are modeled and solved by operations research (OR) methods. The vast majority of the literature reviewed $[1,2,3,4]$, have formulated SC models as linear programming (LP), integer programming (IP) and mixed integer linear programming (MILP) problems. Declarative environments such as CLP facilitate problem modeling and introduction of logical and symbolic constraints [5,6]. Unfortunately, high complexity and the multiple types of constraints of decision-making models as well as combinatorial nature contribute to poor efficiency of modeling in OR methods and inefficient optimization in CLP. Therefore, a new approach to modeling and solving such problems was developed [7,8,9,10]. A declarative environment was chosen as the best structure for this approach especially in modeling [5]. Mathematical programming environment was used for problem optimization [11]. This integrated approach is the basis for the creation of the implementation environment to support managers. 


\section{A. Problem description-illustrative example}

The problem of supply chain management considered here refers to the supply chain in which:

- the supply chain consists of factories, distribution centers and customers (Fig. 1);

- customer orders are executed by deliveries from distribution centers;

- distribution centers are supplied by the factory;

- transport is multimodal (several modes of transport, a limited number of means of transport for each mode);

- the environmental aspects of use of transport modes are taken into account;

- different products are combined in one batch of transport;

- the cost of supplies is presented in the form of a function (in this approach, linear function of fixed and variable costs).

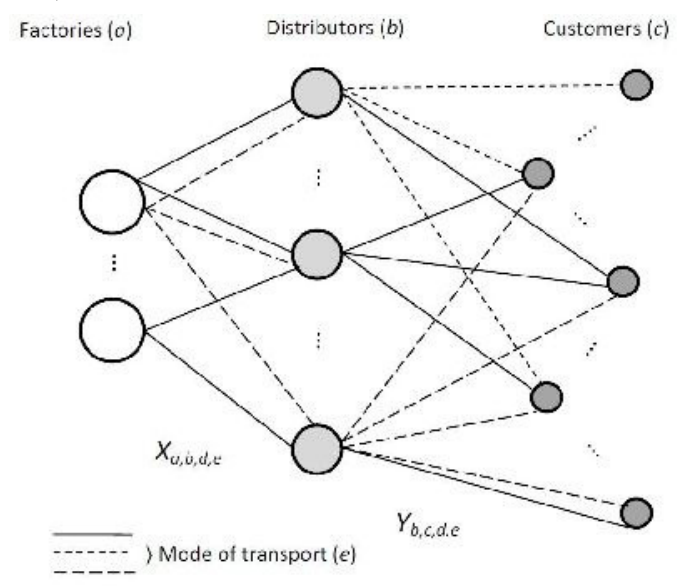

Fig. 1 The structure of supply chain for illustrative example

There are many decision and optimization problems in such supply chain management environment. Specific management problems are presented in the form of questions (possible questions $(\mathrm{Q}$ i) for illustrative example are shown in Table I), which have to meet the reference set of constraints. Indices, and decision variables for the illustrative example have been reported in Table II. The set of reference constraints (1).. (22) for the illustrative example was created and its mathematical/formal notation is included in Appendix A. Brief description of reference set of constraints has been provided below.

Production capacity constraint (1) determines that all deliveries of product $d$ produced by the manufacturer $a$ and delivered to all distributors $b$ using mode of transport $e$ do not exceed the manufacturer's production capacity.

Demand constraint (2) covers all customer $c$ demands for product $d\left(Z_{c, d}\right)$ through the implementation of delivery by distributors $b$ (the values of decision variables $Y_{b, c, d, e}$ ). The flow balance of each distributor $b$ corresponds to balance constraint (3). The possibility of delivery is dependent on the distributor's technical capabilities - capacity constraint (4). Time constraint (5) ensures the terms of all deliveries are met. Transport cconstraints (6a), (6b), (7) guarantee deliveries with available transport taken into account. Constraints (8), (9), (10) set values of decision variables based on binary variables $T c_{b}, X a_{a, b, e}, Y a_{b, c, e}$. Dependencies (11) and (12) represent the relationship based on which total costs are calculated. In general, these may be any linear functions. The remaining constraints (13)..(22) arise from the nature of the decision variables.

TABLE I.

THE SET OF QUESTIONS (INCLUDING BUT NOT LIMITED TO)

\begin{tabular}{l|l|}
\hline Question & \multicolumn{1}{|c|}{ Description } \\
\hline Q_1 & What is the minimum overall cost of timely supply? \\
\hline Q_2 & $\begin{array}{l}\text { Can timely supply be realized at the set cost of } \\
\text { transportation } K t \text { ? }\end{array}$ \\
\hline Q_3 & $\begin{array}{l}\text { What is the minimum environmental cost } K s \text { of timely } \\
\text { supply? }\end{array}$ \\
\hline Q_4 & $\begin{array}{l}\text { What is the minimum cost of timely supply with the use } \\
\text { of no more than } N \text { distribution centers? }\end{array}$ \\
\hline Q_5 & $\begin{array}{l}\text { Is timely supply possible without the use of transport } \\
\text { means } d x \text { ? }\end{array}$ \\
\hline Q_6 & $\begin{array}{l}\text { Is timely supply possible with the following numbers of } \\
\text { transport means } d 1, d 2, d 3 ?\end{array}$ \\
\hline Q_7 & $\begin{array}{l}\text { Can timely supply be realized at the set production cost } \\
K p ?\end{array}$ \\
\hline Q_8 & $\begin{array}{l}\text { What is the minimum cost of supply execution if } \\
\text { transport means } d 1, d 2 \text { cannot be used simultaneously by } \\
\text { distribution center } S 1 \text { ? }\end{array}$ \\
\hline
\end{tabular}

Decision variables of this problem are shown in Table II.

TABLE II.

INDICES AND DECISION VARIABLES

\begin{tabular}{|c|c|}
\hline Symbol & Description \\
\hline \multicolumn{2}{|r|}{ Indices } \\
\hline $\mathrm{d}$ & product type $(\mathrm{d}=1 . . \mathrm{D})$ \\
\hline $\mathrm{c}$ & delivery point/customer/city $(\mathrm{c}=1 . . \mathrm{C})$ \\
\hline a & manufacturer/factory $(a=1 . . A)$ \\
\hline $\mathrm{b}$ & distributor /distribution center $(b=1 . . B)$ \\
\hline $\mathrm{e}$ & mode of transport $(\mathrm{e}=1 . . \mathrm{e})$ \\
\hline A & number of manufacturers/factories \\
\hline $\mathrm{C}$ & number of delivery points/customers \\
\hline $\mathrm{B}$ & number of distributors \\
\hline $\mathrm{D}$ & number of product types \\
\hline $\mathrm{E}$ & number of mode of transport \\
\hline \multicolumn{2}{|r|}{ Decision Variables } \\
\hline$X_{a, b, d, e}$ & $\begin{array}{l}\text { delivery quantity of product } d \text { from manufacturer } a \text { to } \\
\text { distributor } b \text { using mode of transport } e\end{array}$ \\
\hline $\mathrm{Xa}_{\mathrm{a}, \mathrm{b}, \mathrm{e}}$ & $\begin{array}{l}\text { if delivery is from manufacturer } a \text { to distributor } b \text { using mode } \\
\text { of transport } e \text { then } X a_{a, b, e}=1 \text {, otherwise } X a_{a, b, e}=0\end{array}$ \\
\hline $\mathrm{Xb}_{\mathrm{a}, \mathrm{b}, \mathrm{e}}$ & $\begin{array}{l}\text { the number of courses from manufacturer } a \text { to distributor } b \\
\text { using mode of transport } e\end{array}$ \\
\hline$Y_{b, c, d, e}$ & $\begin{array}{l}\text { delivery quantity of product } d \text { from distributor } b \text { to customer } \\
c \text { using mode of transport } e\end{array}$ \\
\hline $\mathrm{Ya}_{\mathrm{b}, \mathrm{c}, \mathrm{e}}$ & $\begin{array}{l}\text { if delivery is from distributor } b \text { to customer } c \text { using mode of } \\
\text { transport } e \text { then } Y a_{b, c, e}=1 \text {, otherwise } Y a_{b, c, e}=0\end{array}$ \\
\hline $\mathrm{Yb}_{\mathrm{b}, \mathrm{c}, \mathrm{e}}$ & $\begin{array}{l}\text { the number of courses from distributor } b \text { to customer } c \text { using } \\
\text { mode of transport } e\end{array}$ \\
\hline $\mathrm{Tc}_{\mathrm{b}}$ & $\begin{array}{l}\text { if distributor } b \text { participates in deliveries, then } T c_{b}=1 \text {, } \\
\text { otherwise } T c_{b}=0\end{array}$ \\
\hline
\end{tabular}




\section{A DECLARATIVE DECISION SUPPORT FRAMEWORK FOR SUPPLY CHAIN MANAGEMENT PROBLEMS-CONCEPT AND IMPLEMENTATION}

The declarative decision support framework was proposed for supply chain management problems. The concept is based on the declarative programming paradigm, which allows high level programming with the use of predicates and facts. Due to the character of problems in the supply chain management, CLP (Constraint Logic Programming) was selected from among many declarative options. The implementation of the framework was performed with the use of ECL ${ }^{\mathrm{i}} \mathrm{PS} \mathrm{S}^{\mathrm{e}}[5,12]$.

The following general assumptions were applied:

- possibility of modeling constraints of any type;

- automatic generation of implementation models in the form of MILP models;

- data recorded as facts.

Figure 2 presents the general concept of the framework. The framework comprises several phases: modeling, presolving, generating and solving. It has two inputs and uses the set of facts. Inputs are the set of questions and the set of constraints to the reference model of a given problem. Based on them, the primary model of the problem is generated as a CLP model, which is then presolved. The built-in CLP method (constraint propagation $[5,6]$ ) and the method of problem transformation designed by the authors [8,9] (Section 3A) are used for this purpose. Presolving procedure results on the transformed model $\mathrm{CLP}^{\mathrm{T}}$. This model is the basis for the automatic generation of the MILP (Mixed Integer Linear Programming) model, which is solved in MP (with the use of an external solver or as a library of CLP). The general concept of the framework consists in modeling and presolving of a problem in the CLP environment with the final solution (including optimization) found in the MP environment. This approach is the result of experience as well as extensive research devoted to both environments and their integration [10,13,14,15,16,17]. In all its phases, the framework uses the set of facts having the structure appropriate for the problem being modeled and solved (Fig. 2). The set of facts is the informational layer of the framework, which can be implemented as a relational database, XML database, etc.

The functional layer comprises adequate sets of predicates: P_1 (CLP model generation), P_2 (CLP model presolving through constraint propagation and transformation, post-transformation generation of $\mathrm{CLP}^{\mathrm{T}}$ model), and $\mathrm{P} \_3$ (generation of the final $\mathrm{MILP}^{\mathrm{T}}$ model in the format of the MP solver).

The presolving phase is an important element of the framework as it makes it possible to simplify the model for the problem being solved and to reduce the combinatorial search space.

For the presolving phase to be effective, unfeasible combinations of model dimensions have to occur. In practice, unfeasible combinations of the index of decision variables and/or facts occur. The proposed framework uses constraint propagation and transformation for the presolving procedure. Constraint propagation is a concept and method that appears in constrained-based environments. Constraint propagation embeds any reasoning which consists in explicity forbiding values from some varable domain of a problem, because all constraints can not be satisfied otherwise [6].

Transformation transforms decision variables of the problem along with constraints and facts. The transformation of facts for the illustrative example is shown in Fig. 3, and the post-transformation variables are compiled in Table AII.

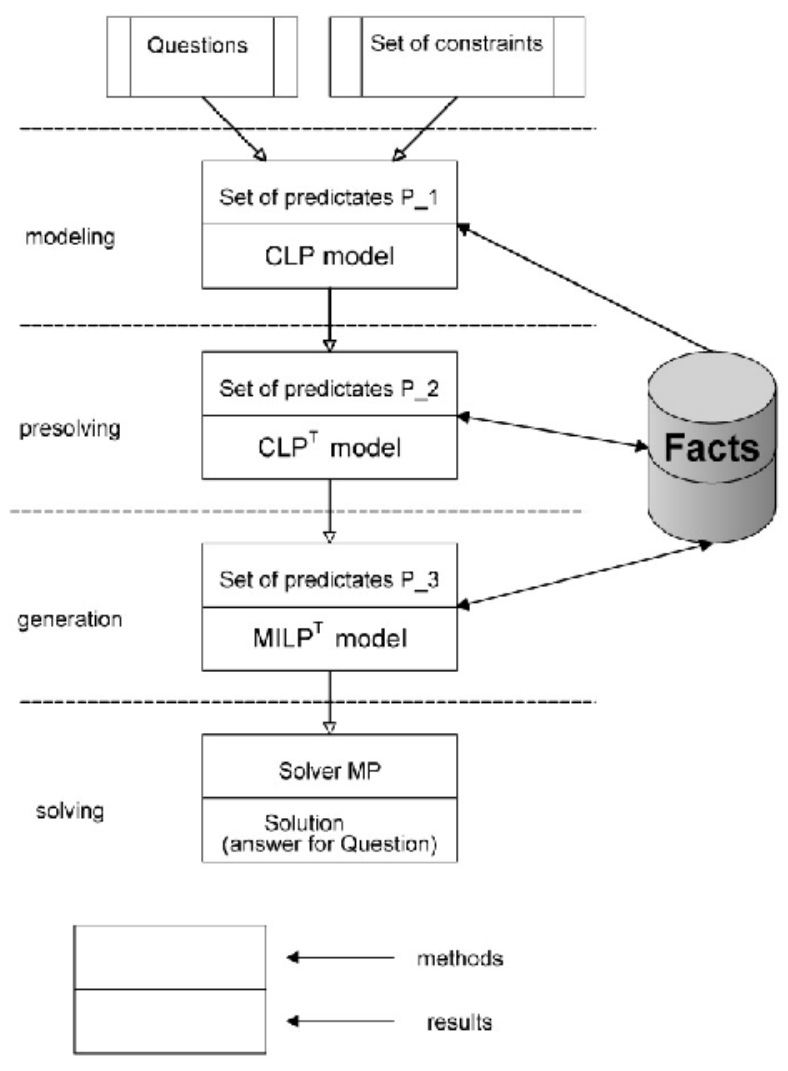

Fig. 2 A concept of a declarative decision support framework

\section{A. Transformation of the problem-presolving phase}

In the case of the problem presented, the transformation consisted in changing the problem representation from graph to routing. Instead of analyzing all possible trnasport connections from the factory to the distribution center and then from the center to the customer, only the feasible connections (factory-center-customer) were generated and named routes. This resulted in the removal of certain indices and in the aggregation of other indices for decision variables, parameters, etc., which eventually led to the reduction in the number of decision variables and constraints $[7,8]$. The new set of decision variable, constraints and facts was the basis for creating the CLP ${ }^{\mathrm{T}}$ model. 


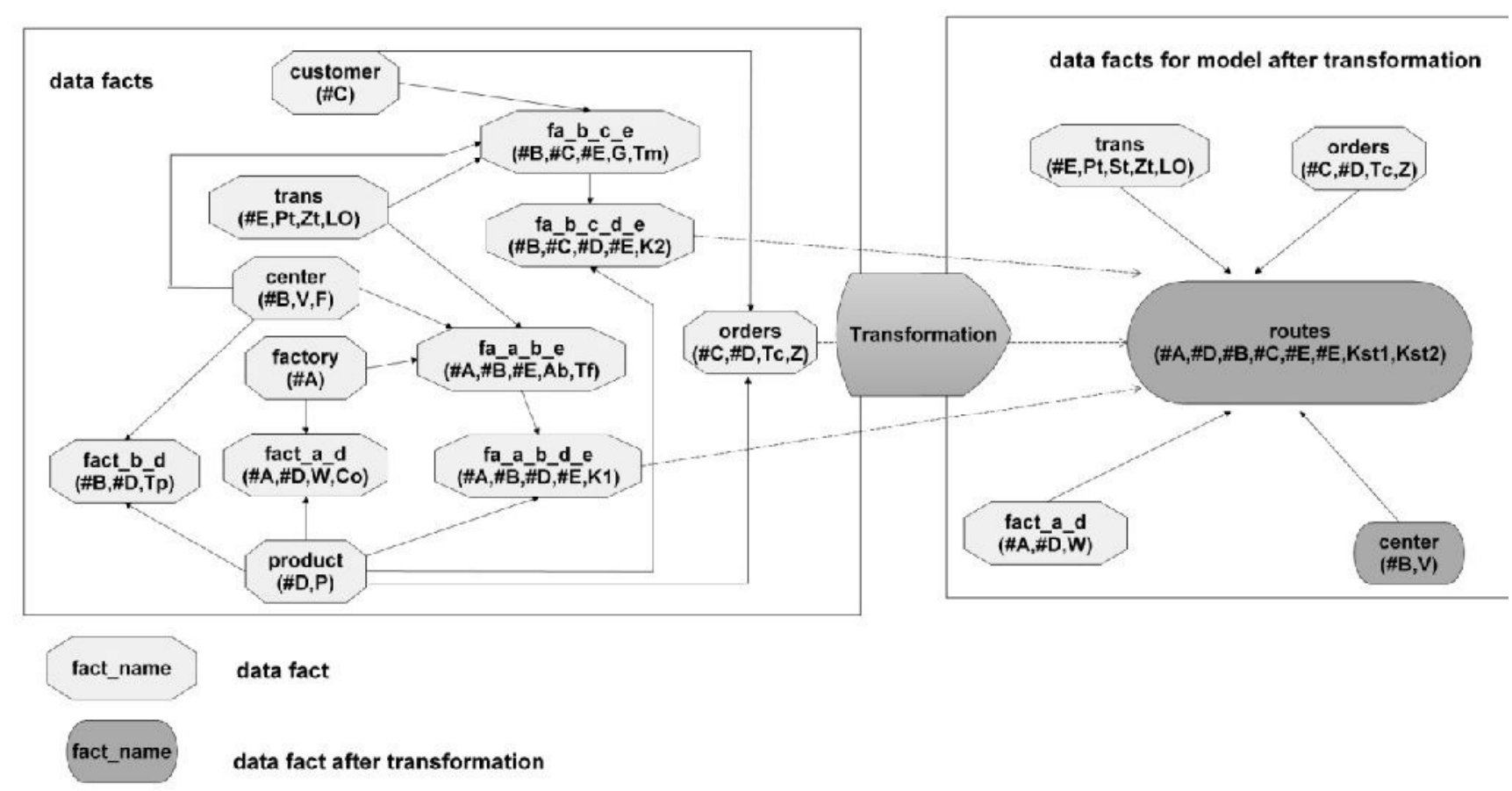

Fig. 3 Structure of facts for illustrative example before and after transformation

\section{COMPUTATION EXAMPLES FOR ILLUSTRATIVE MODEL}

In order to verify and evaluate the proposed approach, many numerical experiments were performed. All the examples relate to the supply chain with five factories $(a=1 . .5)$, four distributor centers $(b=1 . .4)$, fifteen customers $(c=1 . .15)$, four modes of transport $(e=1 . .4)$, and fifteen types of products $(d=1 . .15)$ and fifty orders $(N o)$.

All data instances for these experiments were recorded in the form of facts and included Appendix B. The structure of facts and their description has been shown in Fig. 3 and Table V.

Computational experiments consisted in asking questions Q_1..Q_8 to illustrative example. For each question was generated and solved suitable implementation model using declarative decision support framework. The answers to these questions are shown in Table III.

The answer to question Q_1 is the minimum entire cost of timely delivery all orders (Table III). This cost is the aggregate costs of the entire chain and consists of five elements (23). The first element comprises the fixed costs associated with the operation of the distributor involved in the delivery (e.g. distribution centre, warehouse, etc.). The second element corresponds to environmental costs of using various means of transport. Those costs are dependent on the number of courses of the given means of transport, and on the other hand, on the environmental levy, which in turn may depend on the use of fossil fuels and carbon-dioxide emissions. The third and fourth element determined by the cost of transportation. The last element is the cost of production. The answer to question Q_2 defines the feasibility of timely supply/delivery at the set (closed) transportation cost (25). Table II shows two versions of the question with different parameters. The answer to question Q_3 determines minimum environmental costs (26) of timely delivery (Table I).

Two versions of the answer to question Q_4 are shown in Table III. These versions define the minimum overall cost of timely delivery when two distribution centers are used $\left(Q \_4_{A}\right)$ and when one distribution center is used (Q_4 $\left.4_{B}\right)$.

The possibility of executing timely delivery without the use of selected transportation means is defined in the answer to question Q_5 (three versions of the question are shown in Table III). The answer to question Q_6 specifies the possibility of timely delivery at the set number of each transportation means (Table III).

The possibility of executing timely delivery at the established, closed production cost (24) is included in the answer to question Q_7. Table III shows three versions of the answer. The answer to question Q_8 specifies the minimum cost of timely delivery at the logical condition met, ruling out the possibility of that the selected center can be used concurrently by two different transportation means.

In the second phase of the experiments, a comparative analysis was performed for questions Q_1 and Q_8 (most compute-intensive of all) for different numbers of orders (No) in two environments (declarative decision support framework $\left(\mathrm{MILP}^{\mathrm{T}}\right)$ and MP (MILP)) to evaluate the effectiveness and efficiency of the proposed framework relative to the classical MP environment.

Obtained more than 50-fold reduction of time searching for solutions (Table IV). This is due to the fact that the application of the framework has allowed the up to 50-fold 
reduction of integer decision variables up to 20 -fold reduction of constraints (Table IV).

TABLE III.

ANSWERS TO QUESTION FOR ILLUSTRATIVE EXAMPLE

\begin{tabular}{|c|c|c|}
\hline Question & Parameters & Answer \\
\hline Q_1 & ---- & 17805 \\
\hline Q_2 $2_{\mathrm{A}}$ & $\mathrm{Kt} \leq 1520, \mathrm{~T} \leq 15$ & YES \\
\hline Q_2 & $\mathrm{Kt} \leq 1400, \mathrm{~T} \leq 20$ & $\mathrm{NO}$ \\
\hline Q_3 & ---- & 6250 \\
\hline Q_ 4 A & $\mathrm{N}=2$ & 17945 \\
\hline Q_4 & $\mathrm{N}=1$ & 18126 \\
\hline Q_5 & $\mathrm{S}_{1}=0, \mathrm{~T}=12$ & YES \\
\hline Q_5 B & $\mathrm{S}_{2}=0, \mathrm{~T}=12$ & YES \\
\hline Q_5c & $\mathrm{S}_{3}=0, \mathrm{~T}=12$ & NO \\
\hline Q_6 6 & $\mathrm{S}_{1}=5, \mathrm{~S}_{2}=5, \mathrm{~S}_{3}=5, \mathrm{~S}_{4}=5, \mathrm{~T}=9$ & YES \\
\hline Q_6 & $\mathrm{S}_{1}=5, \mathrm{~S}_{2}=5, \mathrm{~S}_{3}=5, \mathrm{~S}_{4}=5, \mathrm{~T}=9$ & NO \\
\hline Q_6 $6_{C}$ & $\begin{array}{c}\mathrm{S}_{1}=5, \mathrm{~S}_{2}=5, \mathrm{~S}_{3}=5 \\
\mathrm{~S}_{4}=5, \mathrm{~T}=12\end{array}$ & YES \\
\hline Q_7 & $\mathrm{Kp} \leq 9820, \mathrm{~T} \leq 8$ & NO \\
\hline Q_7B & $\mathrm{Kp} \leq 9820, \mathrm{~T} \leq 12$ & YES \\
\hline Q_7C & $\mathrm{Kp} \leq 39200, \mathrm{~T} \leq 8$ & YES \\
\hline Q_8 & ---- & 17856 \\
\hline
\end{tabular}

TABLE IV.

NUMERICAL EXPERIMENTS ON THE EFFICIENCY

\begin{tabular}{|c|c|c|c|c|c|}
\hline No & Model & Vint & C & Answer & T \\
\hline \multicolumn{6}{|c|}{ Q_1 } \\
\hline \multirow[t]{2}{*}{10} & MILP & 45286 & 29510 & 5500 & 26 \\
\hline & MILP $^{\mathrm{T}}$ & 860 & 1590 & 5500 & 2 \\
\hline \multirow[t]{2}{*}{25} & MILP & 45286 & 33990 & 9100 & 101 \\
\hline & MILP $^{\mathrm{T}}$ & 1268 & 1596 & 9100 & 2 \\
\hline \multirow[t]{2}{*}{50} & MILP & 45286 & 41990 & 17805 & 545 \\
\hline & MILP $^{\mathrm{T}}$ & 2078 & 1603 & 17805 & 13 \\
\hline \multirow[t]{2}{*}{75} & MILP & 45286 & 49990 & $27695^{*}$ & $600^{* *}$ \\
\hline & MILP $^{\mathrm{T}}$ & 2996 & 1612 & 27175 & 56 \\
\hline \multicolumn{6}{|c|}{ Q_8 } \\
\hline \multirow[t]{2}{*}{10} & MILP & 45290 & 29518 & 5610 & 45 \\
\hline & MILP $^{\mathrm{T}}$ & 864 & 1590 & 5610 & 3 \\
\hline \multirow[t]{2}{*}{25} & MILP & 45290 & 33998 & 9210 & 112 \\
\hline & MILP $^{\mathrm{T}}$ & 1272 & 1604 & 9210 & 2 \\
\hline \multirow[t]{2}{*}{50} & MILP & 45290 & 41998 & 17856 & 588 \\
\hline & MILP $^{\mathrm{T}}$ & 2082 & 1611 & 17856 & 14 \\
\hline \multirow[t]{2}{*}{75} & MILP & 45290 & 49998 & 28102 & $600^{* *}$ \\
\hline & MILP $^{\mathrm{T}}$ & 3000 & 1620 & 27450 & 68 \\
\hline
\end{tabular}

No-the number of orders; Vint-the number of integer decision variables, $\mathbf{C}$ the number of constraints, T-time of finding solution (in seconds)
TABLE V.

STRUCTURE OF THE FACTS FOR ILLUSTRATIVE EXAMPLE

\begin{tabular}{|c|c|}
\hline Fact & Description \\
\hline product( $\# \mathrm{D}, \mathrm{P})$. & $\begin{array}{l}\text { products, D-product ID, P-the capacity } \\
\text { occupied by product. }\end{array}$ \\
\hline factory(\#A). & factories, A-factory ID. \\
\hline fact_a_d $(\# A, \# D, W, C o)$ & $\begin{array}{l}\text { products in factories, A-factory ID, D- } \\
\text { product } \mathrm{ID} \text {, W-production capacity at } \\
\text { factory } \mathrm{A} \text { for product } \mathrm{D}, \text { Co-the cost of } \\
\text { product } \mathrm{D} \text { in factory } \mathrm{A} \text {. }\end{array}$ \\
\hline center $(\# \mathrm{~B}, \mathrm{~V}, \mathrm{~F})$ & $\begin{array}{l}\text { distribution centers, B-center ID, V- } \\
\text { maximum capacity, F-the fixed cost of } \\
\text { distribution center. }\end{array}$ \\
\hline fact_b_d(\#B,\#D,Tp) & $\begin{array}{l}\text { products in distribution centers, B-center } \\
\text { ID, D-product ID, Tp-the time needed } \\
\text { for distributor B to prepare the shipment } \\
\text { of product D. }\end{array}$ \\
\hline $\operatorname{trans}(\# \mathrm{E}, \mathrm{Pt}, \mathrm{Zt}, \mathrm{Od})$ & $\begin{array}{l}\text { transportation, E-number of mode of } \\
\text { transportation, Pt-the capacity of } \\
\text { transport unit, St-payload,Zt-the number } \\
\text { of transport units using mode of } \\
\text { transportation E, Od-the environmental } \\
\text { cost }\end{array}$ \\
\hline customer(\#C) & customers, C-ustomer ID \\
\hline fa_a_b_e( $\# A, \# B, \# E, A b, T f)$ & $\begin{array}{l}\text { delivery from factory to distribution } \\
\text { center using mode of transportation E, } \\
\text { A-factory ID, B-center ID, E-number of } \\
\text { mode of transportation, Ab-the fixed } \\
\text { cost of delivery, Tf-the time of delivery }\end{array}$ \\
\hline fa_b_c_e( $\# B, \# C, \# E, G, T m)$ & $\begin{array}{l}\text { delivery from distribution center to } \\
\text { customer using mode of transportation } \\
\text { E, B-center ID, C-customer ID, E- } \\
\text { number of mode of transportation, G-the } \\
\text { fixed cost of delivery, Tm-the time of } \\
\text { delivery }\end{array}$ \\
\hline fa_a_b_d_e $(\# A, \# B, \# D, \# E, K 1)$ & $\begin{array}{l}\text { the variable costs of delivery of product, } \\
\text { A-factory ID, B-center ID, D-product } \\
\text { ID, E-number of mode of transportation, } \\
\text { Ks3-the variable cost of delivery of } \\
\text { product from factory to distribution } \\
\text { center (optional) }\end{array}$ \\
\hline fa_b_c_d_e(\#B,\#C,\#D,\#E,K2) & $\begin{array}{l}\text { the variable costs of delivery of product, } \\
\text { B-center ID, C-customer ID, D-product } \\
\text { ID, E-number of mode of transportation, } \\
\text { Ks4-the variable cost of delivery of } \\
\text { product from distribution center to } \\
\text { customer (optional) }\end{array}$ \\
\hline orders(\#C,\#D,Tc,Z) & $\begin{array}{l}\text { orders, C-customer ID, D-product ID, } \\
\text { the cut-off time of delivery to customer } \\
\text { of product, Z-customer demand for } \\
\text { product }\end{array}$ \\
\hline
\end{tabular}

\section{V.CONCLUSIONS}

Two types of questions can be asked in the proposed declarative decision support framework.

General questions may require domain solution, which in practice determines the availability of capacity, the number of transport units, timely supply etc. The specific whquestions will in practice define the best, fastest, cheapest, or the most expensive of the possible solutions. To obtain answers to these questions, optimization is necessary. Both 
question types can contain logical conditions relating, for example, to the disjoint use of transport units, distributors, etc. The illustrative example shows only part of potential of the framework designed to increase both the speed and the size of the problems solved (Table IV).

This is particularly evident if we compare the possibilities of the framework in relation to the classical approach based on mathematical programming (Table IV).

Further work will consist in the implementation of more complex models [18], uncertainty, fuzzy logic etc. [19], and as a cloud internet application [20]. New questions will be implemented to broaden the scope of decision support.

It is also considering development of models to take account product demand interdependencies [21]. In the future it is planned to integrate framework with ERP and APS systems [22]. It is planned to also use a hybrid approach to optimize the use of graphs, for example, to image retrieval [23].

\section{APPENDIX A}

TABLE A1

SUMMARY PARAMETERS

\begin{tabular}{|c|c|}
\hline Symbol & Description \\
\hline \multicolumn{2}{|r|}{ Input parameters } \\
\hline $\mathrm{F}_{\mathrm{b}}$ & the fixed cost of distributor/distribution center $b$ \\
\hline $\mathrm{P}_{\mathrm{d}}$ & the area/volume occupied by product $d$ \\
\hline $\mathrm{V}_{\mathrm{b}}$ & distributor $b$ maximum capacity/volume \\
\hline $\mathrm{W}_{\mathrm{a}, \mathrm{d}}$ & production capacity at factory $a$ for product $d$ \\
\hline $\mathrm{Co}_{\mathrm{a}, \mathrm{d}}$ & the cost of product $d$ at factory $a$ \\
\hline $\mathrm{R}_{\mathrm{b}, \mathrm{d}}$ & $\begin{array}{l}\text { if distributor } b \text { can deliver product } d \text { then } R_{b, d}=1 \text {, otherwise } \\
R_{b, d}=0\end{array}$ \\
\hline $\mathrm{Tp}_{\mathrm{b}, \mathrm{d}}$ & $\begin{array}{l}\text { the time needed for distributor } b \text { to prepare the shipment of } \\
\text { product } d\end{array}$ \\
\hline $\mathrm{Tc}_{\mathrm{c}, \mathrm{d}}$ & $\begin{array}{l}\text { the cut-off time of delivery to the delivery point/customer } c \\
\text { of product } d\end{array}$ \\
\hline$Z_{c, d}$ & customer demand/order $c$ for product $d$ \\
\hline $\mathrm{Zt}_{\mathrm{e}}$ & the number of transport units using mode of transport $e$ \\
\hline $\mathrm{Pt}_{\mathrm{e}}$ & the capacity of transport unit using mode of transport $e$ \\
\hline $\mathrm{Tf}_{\mathrm{a}, \mathrm{b}, \mathrm{e}}$ & $\begin{array}{l}\text { the time of delivery from manufacturer } a \text { to distributor } b \\
\text { using mode of transport } e\end{array}$ \\
\hline $\mathrm{St}_{\mathrm{e}}$ & the payload of transport unit using mode of transport $e$ \\
\hline $\mathrm{K} 1_{\mathrm{a}, \mathrm{b}, \mathrm{d}, \mathrm{e}}$ & $\begin{array}{l}\text { the variable cost of delivery of product } d \text { from manufacturer } \\
a \text { to distributor } b \text { using mode of transport } e\end{array}$ \\
\hline $\mathrm{R} 1_{\mathrm{a}, \mathrm{b}, \mathrm{e}}$ & $\begin{array}{l}\text { if manufacturer } a \text { can deliver to distributor } b \text { using mode of } \\
\text { transport } e \text { then } R 1_{a, b, e}=1 \text {, otherwise } R 1_{a, b, e}=0\end{array}$ \\
\hline $\mathrm{A}_{\mathrm{a}, \mathrm{b}, \mathrm{e}}$ & $\begin{array}{l}\text { the fixed cost of delivery from manufacturer } a \text { to distributor } b \\
\text { using mode of transport } e\end{array}$ \\
\hline $\mathrm{Koa}_{\mathrm{b}, \mathrm{c}, \mathrm{e}}$ & $\begin{array}{l}\text { the total cost of delivery from distributor } b \text { to customer } c \\
\text { using mode of transport } e\end{array}$ \\
\hline $\mathrm{Tm}_{\mathrm{b}, \mathrm{c.e}}$ & $\begin{array}{l}\text { the time of delivery from distributor } b \text { to customer } c \text { using } \\
\text { mode of transport } e\end{array}$ \\
\hline $\mathrm{K} 2_{\mathrm{b}, \mathrm{c}, \mathrm{d}, \mathrm{e}}$ & $\begin{array}{l}\text { the variable cost of delivery of product } d \text { from distributor } b \text { to } \\
\text { customer } c \text { using mode of transport } e\end{array}$ \\
\hline $\mathrm{R} 2_{\mathrm{b}, \mathrm{c}, \mathrm{e}}$ & $\begin{array}{l}\text { if distributor } b \text { can deliver to customer } c \text { using mode of } \\
\text { transport } e \text { then } R 2_{b, c, e}=1 \text {, otherwise } R 2_{b, c, e}=0\end{array}$ \\
\hline $\mathrm{G}_{\mathrm{b}, \mathrm{c}, \mathrm{e}}$ & $\begin{array}{l}\text { the fixed cost of delivery from distributor } b \text { to customer } c \\
\text { using mode of transport } e\end{array}$ \\
\hline $\operatorname{Kog}_{b, c, e}$ & $\begin{array}{l}\text { the total cost of delivery from distributor } b \text { to customer } c \\
\text { using mode of transport } e\end{array}$ \\
\hline $\mathrm{Od}_{\mathrm{e}}$ & the environmental cost of using mode of transport $e$ \\
\hline $\mathrm{CW}$ & Arbitrarily large constant \\
\hline
\end{tabular}

$\sum_{b=1}^{B} \sum_{e=1}^{E} X_{a, b, d, e} \cdot R_{b, d} \leq W_{a, d} \forall a=1 . . A, d=1 . . D$

$$
\begin{aligned}
& \sum_{b=1}^{B} \sum_{e=1}^{e}\left(Y_{b, c, d, e} \cdot R_{b, d}\right) \geq Z_{c, d} \forall j=c . . C, d=1 . . D \\
& \sum_{\mathrm{a}=1}^{\mathrm{A}} \sum_{\mathrm{e}=1}^{\mathrm{E}} \mathrm{X}_{\mathrm{a}, \mathrm{b}, \mathrm{d}, \mathrm{e}}=\sum_{\mathrm{c}=1}^{\mathrm{C}} \sum_{\mathrm{e}=1}^{\mathrm{E}} \mathrm{Y}_{\mathrm{b}, \mathrm{c}, \mathrm{d}, \mathrm{e}} \forall \mathrm{b}=1 . . \mathrm{B}, \mathrm{d}=1 . . \mathrm{D} \\
& \sum_{\mathrm{d}=1}^{\mathrm{D}}\left(\mathrm{P}_{\mathrm{d}} \cdot \sum_{\mathrm{a}=1}^{\mathrm{A}} \sum_{\mathrm{e}=1}^{\mathrm{E}} \mathrm{X}_{\mathrm{a}, \mathrm{b}, \mathrm{d}, \mathrm{e}}\right) \leq \mathrm{Tc}_{\mathrm{b}} \cdot \mathrm{V}_{\mathrm{b}} \forall \mathrm{b}=1 . . \mathrm{B} \\
& \mathrm{Xa}_{\mathrm{a}, \mathrm{b}, \mathrm{e}} \cdot \mathrm{Tf}_{\mathrm{a}, \mathrm{b}, \mathrm{e}}+\mathrm{Xa}_{\mathrm{a}, \mathrm{b}, \mathrm{e}} \cdot \mathrm{Tp}_{\mathrm{b}, \mathrm{d}}+\mathrm{Ya}_{\mathrm{b}, \mathrm{c}, \mathrm{e}} \cdot \mathrm{Tm}_{\mathrm{b}, \mathrm{ce}, \mathrm{e}} \leq \mathrm{Tc}_{\mathrm{b}, \mathrm{d}} \\
& \forall \mathrm{a}=1 . . \mathrm{A}, \mathrm{b}=1 . . \mathrm{B}, \mathrm{C}=1 . . \mathrm{C}, \mathrm{d}=1 . . \mathrm{D}, \mathrm{e}=1 . . \mathrm{E} \\
& \mathrm{R}_{\mathrm{a}, \mathrm{be}} \cdot \mathrm{Xb}_{\mathrm{a}, \mathrm{b}, \mathrm{e}} \cdot \mathrm{Pt}_{\mathrm{e}} \geq \mathrm{X}_{\mathrm{a}, \mathrm{b}, \mathrm{d}, \mathrm{e}} \cdot \mathrm{P}_{\mathrm{e}} \\
& \forall \mathrm{a}=1 . . \mathrm{A}, \mathrm{b}=1 . \mathrm{B}, \mathrm{d}=1 . \mathrm{D}, \mathrm{e}=1 . \mathrm{E} \\
& \mathrm{R} 2_{\mathrm{b}, \mathrm{c}, \mathrm{e}} \cdot \mathrm{Yb}_{\mathrm{b}, \mathrm{c}, \mathrm{e}} \cdot \mathrm{Pt} \mathrm{t}_{\mathrm{e}} \geq \mathrm{Y}_{\mathrm{b}, \mathrm{c}, \mathrm{d}, \mathrm{e}} \cdot \mathrm{P}_{\mathrm{e}} \\
& \forall \mathrm{b}=1 . . \mathrm{B}, \mathrm{c}=1 . . \mathrm{C}, \mathrm{d}=1 . . \mathrm{D}, \mathrm{e}=1 . . \mathrm{E} \\
& \sum_{\mathrm{a}=1}^{\mathrm{A}} \sum_{\mathrm{b}=1}^{\mathrm{B}} \mathrm{Xb}_{\mathrm{a}, \mathrm{b}, \mathrm{e}}+\sum_{\mathrm{b}=1}^{\mathrm{B}} \sum_{\mathrm{c}=1}^{\mathrm{C}} \mathrm{Yb}_{\mathrm{b}, \mathrm{c}, \mathrm{e}} \leq \mathrm{Zt} \mathrm{e}, \forall \mathrm{e}=1 . . \mathrm{E} \\
& \sum_{\mathrm{a}=1}^{\mathrm{A}} \sum_{\mathrm{e}=1}^{\mathrm{E}} \mathrm{Xb}_{\mathrm{a}, \mathrm{b}, \mathrm{e}} \leq \mathrm{CW} \cdot \mathrm{Tc}_{\mathrm{e}} \forall \mathrm{e}=1 . . \mathrm{E} \\
& \mathrm{Xb}_{\mathrm{a}, \mathrm{b}, \mathrm{e}} \leq \mathrm{CW} \cdot \mathrm{Xa}_{\mathrm{a}, \mathrm{b}, \mathrm{e}} \forall \mathrm{a}=1 . . \mathrm{A}, \mathrm{b}=1 . . \mathrm{B}, \mathrm{e}=1 . . \mathrm{E} \\
& \mathrm{Yb}_{\mathrm{b}, \mathrm{c}, \mathrm{e}} \leq \mathrm{CW} \cdot \mathrm{Ya}_{\mathrm{b}, \mathrm{c}, \mathrm{e}} \forall \mathrm{b}=1 . . \mathrm{B}, \mathrm{c}=1 . . \mathrm{C}, \mathrm{e}=1 . . \mathrm{E} \\
& \mathrm{Koa}_{\mathrm{a}, \mathrm{b}, \mathrm{e}}=\mathrm{Ab}_{\mathrm{a}, \mathrm{b}, \mathrm{e}} \cdot \mathrm{Xb}_{\mathrm{a}, \mathrm{b}, \mathrm{e}}+\sum_{\mathrm{d}=1}^{\mathrm{D}} \mathrm{K} 1_{\mathrm{a}, \mathrm{b}, \mathrm{d}, \mathrm{e}} \cdot \mathrm{X}_{\mathrm{a}, \mathrm{b}, \mathrm{d}, \mathrm{e}} \\
& \forall \mathrm{a}=1 . . \mathrm{A}, \mathrm{b}=1 . . \mathrm{B}, \mathrm{e}=1 . . \mathrm{E} \\
& \mathrm{Kog}_{\mathrm{b}, \mathrm{c}, \mathrm{e}}=\mathrm{G}_{\mathrm{b}, \mathrm{c}, \mathrm{e}} \cdot \mathrm{Yb}_{\mathrm{b}, \mathrm{c}, \mathrm{e}}+\sum_{\mathrm{d}=1}^{\mathrm{D}} \mathrm{K} 2_{\mathrm{b}, \mathrm{c}, \mathrm{d}, \mathrm{e}} \cdot \mathrm{Y}_{\mathrm{b}, \mathrm{c}, \mathrm{d}, \mathrm{e}} \\
& \forall \mathrm{b}=1 . . \mathrm{B}, \mathrm{c}=1 . . \mathrm{C}, \mathrm{e}=1 . . \mathrm{E} \\
& \mathrm{X}_{\mathrm{a}, \mathrm{b}, \mathrm{d}, \mathrm{e}} \geq 0 \forall \mathrm{a}=1 . . \mathrm{A}, \mathrm{b}=1 . . \mathrm{B}, \mathrm{d}=1 . . \mathrm{D}, \mathrm{e}=1 . . \mathrm{E} \\
& \mathrm{Xb}_{\mathrm{a}, \mathrm{b}, \mathrm{e}} \geq 0 \forall \mathrm{a}=1 . . \mathrm{A}, \mathrm{b}=1 . . \mathrm{B}, \mathrm{e}=1 . . \mathrm{E} \\
& \mathrm{Yb}_{\mathrm{b}, \mathrm{c}, \mathrm{e}} \geq 0 \forall \mathrm{b}=1 . . \mathrm{B}, \mathrm{c}=1 . . \mathrm{C}, \mathrm{e}=1 . . \mathrm{E} \\
& \mathrm{X}_{\mathrm{a}, \mathrm{b}, \mathrm{d}, \mathrm{e}} \in \mathrm{C} \forall \mathrm{a}=1 . . \mathrm{A}, \mathrm{b}=1 . . \mathrm{B}, \mathrm{d}=1 . . \mathrm{D}, \mathrm{e}=1 . . \mathrm{E} \\
& \mathrm{Xb}_{\mathrm{a}, \mathrm{b}, \mathrm{e}} \in \mathrm{C} \forall \mathrm{a}=1 . . \mathrm{A}, \mathrm{b}=1 . . \mathrm{B}, \mathrm{e}=1 . . \mathrm{E} \\
& \mathrm{Y}_{\mathrm{b}, \mathrm{c}, \mathrm{d}, \mathrm{e}} \in \mathrm{C} \forall \mathrm{b}=1 . . \mathrm{B}, \mathrm{c}=1 . . \mathrm{C}, \mathrm{d}=1 . . \mathrm{D}, \mathrm{e}=1 . . \mathrm{E} \\
& \mathrm{Yb}_{\mathrm{b}, \mathrm{c}, \mathrm{d}} \in \mathrm{C} \forall \mathrm{b}=1 . . \mathrm{B}, \mathrm{c}=1 . . \mathrm{C}, \mathrm{e}=1 . . \mathrm{E} \\
& \mathrm{Xa}_{\mathrm{a}, \mathrm{b}, \mathrm{e}} \in\{0,1\} \forall \mathrm{a}=1 . . \mathrm{A}, \mathrm{b}=1 . . \mathrm{B}, \mathrm{e}=1 . . \mathrm{E} \\
& \mathrm{Ya}_{\mathrm{b}, \mathrm{c}, \mathrm{e}} \in\{0,1\} \forall \mathrm{b}=1 . . \mathrm{B}, \mathrm{c}=1 . . \mathrm{C}, \mathrm{e}=1 . . \mathrm{E} \\
& \mathrm{Tc}_{\mathrm{b}} \in\{0,1\} \forall \mathrm{b}=1 . . \mathrm{B} \\
& \mathrm{K}=\sum_{\mathrm{b}=1}^{\mathrm{B}}\left(\mathrm{F}_{\mathrm{b}} \cdot \mathrm{Tc}_{\mathrm{b}}\right)+\sum_{\mathrm{e}=1}^{\mathrm{E}} \mathrm{Od}_{\mathrm{e}}\left(\sum_{\mathrm{a}=1}^{\mathrm{A}} \sum_{\mathrm{b}=1}^{\mathrm{B}} \mathrm{Xb}_{\mathrm{a}, \mathrm{b}, \mathrm{e}}+\sum_{\mathrm{b}=1}^{\mathrm{B}} \sum_{\mathrm{c}=1}^{\mathrm{C}} \mathrm{Yb}_{\mathrm{b}, \mathrm{c}, \mathrm{e}}\right) \\
& +\sum_{\mathrm{a}=1}^{\mathrm{A}} \sum_{\mathrm{b}=1}^{\mathrm{B}} \sum_{\mathrm{e}=1}^{\mathrm{E}} \mathrm{Koa}_{\mathrm{a}, \mathrm{b}, \mathrm{e}}+\sum_{\mathrm{b}=1}^{\mathrm{B}} \sum_{\mathrm{c}=1}^{\mathrm{C}} \sum_{\mathrm{e}=1}^{\mathrm{E}} \operatorname{Kog}_{\mathrm{s}, \mathrm{j}, \mathrm{d}}+ \\
& \sum_{\mathrm{a}=1}^{\mathrm{A}} \sum_{\mathrm{d}=1}^{\mathrm{D}}\left(\mathrm{Co}_{\mathrm{a}, \mathrm{d}} \cdot \sum_{\mathrm{b}=1}^{\mathrm{B}} \sum_{\mathrm{e}=1}^{\mathrm{E}} \mathrm{X}_{\mathrm{a}, \mathrm{b}, \mathrm{d}, \mathrm{e}}\right) \\
& \mathrm{K}_{\mathrm{p}}=\sum_{\mathrm{a}=1}^{\mathrm{A}} \sum_{\mathrm{d}=1}^{\mathrm{D}}\left(\mathrm{Co}_{\mathrm{a}, \mathrm{d}} \cdot \sum_{\mathrm{b}=1}^{\mathrm{B}} \sum_{\mathrm{e}=1}^{\mathrm{E}} \mathrm{X}_{\mathrm{a}, \mathrm{b}, \mathrm{d}, \mathrm{e}}\right) \\
& \mathrm{K}_{\mathrm{t}}=\sum_{\mathrm{a}=1}^{\mathrm{A}} \sum_{\mathrm{b}=1}^{\mathrm{B}} \sum_{\mathrm{e}=1}^{\mathrm{E}} \mathrm{Koa}_{\mathrm{a}, \mathrm{b}, \mathrm{e}}+\sum_{\mathrm{b}=1}^{\mathrm{B}} \sum_{\mathrm{c}=1}^{\mathrm{C}} \sum_{\mathrm{e}=1}^{\mathrm{E}} \mathrm{Kog}_{\mathrm{s}, \mathrm{j}, \mathrm{d}} \\
& \mathrm{K}_{\mathrm{s}}=\sum_{\mathrm{e}=1}^{\mathrm{E}} \operatorname{Od}_{\mathrm{e}}\left(\sum_{\mathrm{a}=1}^{\mathrm{A}} \sum_{\mathrm{b}=1}^{\mathrm{B}} \mathrm{Xb}_{\mathrm{a}, \mathrm{b}, \mathrm{e}}+\sum_{\mathrm{b}=1}^{\mathrm{B}} \sum_{\mathrm{c}=1}^{\mathrm{C}} \mathrm{Yb}_{\mathrm{b}, \mathrm{c}, \mathrm{e}}\right)
\end{aligned}
$$


TABLE AII.

DECISION VARIABLES AFTER TRANSFORMATION

\begin{tabular}{l|c|}
\hline \multicolumn{2}{c|}{ Decision variables } \\
\hline $\begin{array}{l}\text { delivery quantity of product } d \text { for route from } \\
\text { manufacturer } a \text { to distributor } b \text { using mode of } \\
\text { transport } e_{1} \text { and from distributor } b \text { to customer } c \text { using } \\
\text { mode of transport } e_{2}\end{array}$ & $\mathrm{X}_{\mathrm{a}, \mathrm{b}, \mathrm{c}, \mathrm{d}, \mathrm{e}_{1}, \mathrm{e}_{2}}^{\mathrm{T}}$ \\
\hline $\begin{array}{l}\text { the number of courses from manufacturer } a \text { to } \\
\text { distributor } b \text { using mode of transport } e\end{array}$ & $\mathrm{Xb}_{\mathrm{a}, \mathrm{b}, \mathrm{e}}^{\mathrm{T}}$ \\
\hline $\begin{array}{l}\text { the number of courses from distributor } b \text { to customer } \\
c \text { using mode of transport } e\end{array}$ & $\mathrm{Yb}_{\mathrm{b}, \mathrm{c}, \mathrm{e}}^{\mathrm{T}}$ \\
\hline $\begin{array}{l}\text { if distributor } b \text { participates in deliveries, then } T c_{b}=1, \\
\text { otherwise } T c_{b}=0\end{array}$ & $\mathrm{Tc}_{\mathrm{b}}^{\mathrm{T}}$ \\
\hline
\end{tabular}

\section{APPENDIX B}

\section{○Products}

product $(\mathrm{d} 1,10,2)$. product $(d 3,20,4)$. product $(d 5,10,2)$. product $(d 7,20,3)$. product $(d 9,10,4)$. product $(\mathrm{d} 13,30,3)$. product $(\mathrm{d} 14,30,3)$. product $(\mathrm{d} 15,20,4)$.

\section{\%Factories}

factory(a1). factory(a2). factory(a3). factory (a4). factory (a5).

\section{¿Distribution Centers}

center $(b 1,1000,100)$. center $(b 2,1000,200)$.

center $(\mathrm{b} 3,1000,300)$. center $(\mathrm{b} 4,1000,400)$.

\section{Products in distribution centers}

fact_b_d (b1, d1, 1). fact_b_d (b1, d2, 1) .

fact_b_d(b1, d3,1). fact_b_d(b1, d4,1).

fact_b_d (b1, d5, 1). fact_b_d (b1, d6,1) .

fact_b_d (b1, d7, 1). fact_b_d (b1, d8,1) .

fact_b_d(b1, d9,1). fact_b_d(b1, d10,1).

fact_b_d(b1,d11,1). fact_b_d(b1, d12,1).

fact_b_d (b2, d5 , 1). fact_b_d (b2, d6,1).

fact_b_d (b2, d7, 1). fact_b_d (b2, d8, 1).

fact_b_d (b2, d9, 1). fact_b_d(b2, d10,1).

fact_b_d (b2, d11,1). fact_b_d (b2, d12,1).

fact_b_d (b2, d13,1). fact_b_d (b2, d14, 1$)$.

fact_b_d (b2, d15, 1). fact_b_d (b3, d1, 1$)$.

fact_b_d (b3, d2, 1). fact_b_d (b3, d3, 1) .

fact_b_d(b3,d4,1). fact_b_d (b3, d5, 1).

fact_b_d (b3, d6,1). fact_b_d (b3, d7, 1).

fact_b_d (b3, d8, 1). fact_b_d (b3, d9, 1).

fact_b_d (b3,d10,1). fact_b_d (b3, d11,1).

fact_b_d (b3, d12,1). fact_b_d (b3, d13,1).

fact_b_d (b3, d14,1). fact_b_d (b3, d15, 1).

fact_b_d (b4, d1,1). fact_b_d (b4, d2, 1).

fact_b_d (b4, d3, 1). fact_b_d (b4, d4, 1).

fact_b_d (b4, d5, 1). fact_b_d (b4, d6, 1).

fact_b_d (b4, d7,1). fact_b_d (b4, d8,1).

fact_b_d (b4, d9, 1). fact_b_d (b4, d10,1).

fact_b_d (b4,d11,1). fact_b_d (b4, d12, 1$)$.

fact_b_d (b4, d13,1). fact_b_d (b4, d14,1).

fact_b_d (b4,d15,1).

\section{\%Products infactories}

fact_a_d $(a 1, d 1,800,400)$. fact_a_d $(a 2, d 2,800,400)$. fact_a_d $(a 3, d 3,800,400)$. fact_a_d $(a 1, d 4,800,400)$. fact_a_d $(a 2, d 5,800,400)$. fact_a_d (a3, d6, 800,400). fact_a_d $(a 1, d 7,800,400)$. fact_a_d $(a 2, d 8,800,400)$. fact_a_d $(a 3, d 9,800,400)$. fact_a_d $(a 1, d 10,800,400)$. fact_a_d (a2, d11,800,400).fact_a_d (a3, d12, 800, 400). fact_a_d (a1, d13,800,400).fact_a_d (a2, d14,800, 400). fact_a_d (a3,d15,800,400).fact_a_d (a4, d1,800,100). fact_a_d $(a 4, d 2,800,100)$. fact_a_d $(a 4, d 3,800,100)$. fact_a_d $(a 4, d 4,800,100)$. fact_a_d $(a 4, d 5,800,100)$. fact_a_d $(a 4, d 6,800,100)$. fact_a_d $(a 4, d 7,800,100)$. fact_a_d $(a 4, d 8,800,100)$. fact_a_d $(a 4, d 6,800,100)$. fact_a_d $(a 4, d 7,800,100)$. fact_a_d (a4, d8, 800,100). fact_a_d $(a 4, d 9,800,100)$. fact_a_d $(a 4, d 10,800,100)$. fact_a_d $(a 4, d 11,800,100)$.fact_a_d $(a 4, d 12,800,100)$. fact_a_d $(a 4, d 13,800,100)$.fact_a_d $(24, d 14,800,100)$. fact_a_d $(a 4, d 15,800,100)$.fact_a_d $(a 5, d 1,800,100)$. fact_a_d $(a 5, d 2,800,100)$. fact_a_d $(a 5, d 3,800,100)$. fact_a_d $(a 5, d 4,800,100)$. fact_a_d $(a 5, d 5,800,100)$. fact_a_d $(a 5, d 6,800,100)$. fact_a_d $(a 5, d 7,800,100)$. fact_a_d $(a 5, d 8,800,100)$. fact_a_d (a5, d6, 800, 100). fact_a_d $(a 5, d 7,800,100)$. fact_a_d $(a 5, d 8,800,100)$. fact_a_d $(a 5, d 9,800,100)$. fact_a_d $(a 5, d 10,800,100)$. fact_a_d $(25, d 11,800,100)$. fact_a_d $(25, d 12,800,100)$. fact_a_d $(a 5, d 13,800,100)$.fact_a_d $(a 5, d 14,800,100)$. fact_a_d (a5, d15,800,100).

\section{\%Transportation modes}

trans $(e 1,850,5,500)$. trans $(e 2,600,10,300)$.

trans $(e 3,350,10,200)$. trans $(e 4,150,10,100)$.

oDeliveries from factories to distribution centers fa_a_b_e $(a 1, b 1, e 1,270,1)$.fa_a_b_e $(a 2, b 1, e 1,300,1)$. fa_a_b_e $(a 3, b 1, e 1,400,1)$.fa_a_b_e $(a 4, b 1, e 1,500,8)$. fa_a_b_e $(a 5, b 1, e 1,400,8)$.fa_a_b_e $(a 1, b 1, e 2,170,2)$. fa_a_b_e $(a 2, b 1, e 2,200,2)$.fa_a_b_e $(a 3, b 1, e 2,300,2)$. fa_a_b_e $(a 4, b 1, e 2,400,8)$.fa_a_b_e $(a 5, b 1, e 2,300,8)$. fa_a_b_e $(a 1, b 2, e 1,270,1)$.fa_a_b_e $(a 2, b 2, e 1,300,1)$. fa_a_b_e $(a 3, b 2, e 1,400,1)$.fa_a_b_e $(a 4, b 2, e 1,500,8)$. fa_a_b_e $(a 5, b 2, e 1,400,8)$. fa_a_b_e $(a 1, b 2, e 2,170,1)$. fa_a_b_e $(a 2, b 2, e 2,200,1)$.fa_a_b_e $(a 3, b 2, e 2,300,1)$. fa_a_b_e $(a 4, b 2, e 2,300,8)$. fa_a_b_e $(a 5, b 2, e 2,300,8)$. fa_a_b_e $(a 1, b 3, e 1,270,1)$.fa_a_b_e $(a 2, b 3, e 1,300,1)$. fa_a_b_e $(a 3, b 3, e 1,400,1)$.fa_a_b_e $(a 4, b 3, e 1,500,8)$. fa_a_b_e $(a 5, b 3, e 1,400,8)$.fa_a_b_e $(a 1, b 3, e 2,170,1)$. fa_a_b_e $(a 2, b 3, e 2,200,1)$.fa_a_b_e $(a 3, b 3, e 2,300,1)$. fa_a_b_e $(a 4, b 3, e 2,400,8)$.fa_a_b_e $(a 5, b 3, e 2,300,8)$. fa_a_b_e $(a 1, b 4, e 1,270,1)$.fa_a_b_e $(a 2, b 4, e 1,300,1)$. fa_a_b_e $(a 3, b 4, e 1,400,1)$.fa_a_b_e $(a 4, b 4, e 1,500,8)$. fa_a_b_e $(a 5, b 4, e 1,400,8)$. fa_a_b_e $(a 1, b 4, e 2,170,1)$. fa_a_b_e $(a 2, b 4, e 2,200,1)$.fa_a_b_e $(a 3, b 4, e 2,300,1)$. fa_a_b_e $(a 4, b 4, e 2,400,8)$. fa_a_b_e $(a 5, b 4, e 2,300,8)$. oCustomers

customer(c2). customer(c3). customer(c4). customer(c5). customer(c6). customer(c7). customer(c8). customer(c9). customer(m10). customer(m11). customer(m12). customer (m13). customer (m14). customer (m15).

¿Deliveries from distribution centers to customers fa_b_c_e (b1, c1,e4,30,1). fa_b_c_e (b1, c2, e4, 30,1). fa_b_c_e $(b 1, c 3, e 4,30,1)$. fa_b_c_e $(b 1, c 4, e 4,30,1)$. fa_b_c_e $(b 1, c 5, e 4,30,1)$. fa_b_c_e $(b 1, c 6, e 4,30,1)$. fa_b_c_e $(b 1, c 7, e 4,30,1)$. fa_b_c_e $(b 1, c 8, e 4,30,1)$. fa_b_c_e $(b 1, c 9, e 4,30,1)$. fa_b_c_e $(b 1, m 10, e 4,30,1)$. fa_b_c_e (b1, m11,e4, 30,1). fa_b_c_e (b1, m12, e4, 30, 1). fa_b_c_e $(\mathrm{b} 1, \mathrm{m1} 1, \mathrm{e} 4,30,1)$. fa_b_c_e $(\mathrm{b} 1, \mathrm{m1} 4, \mathrm{e} 4,30,1)$. fa_b_c_e $(b 1, m 15, e 4,30,1)$. fa_b_c_e $(b 2, c 1, e 4,30,1)$. fa_b_c_e $(b 2, c 2, e 4,30,1)$. fa_b_c_e $(b 2, c 3, e 4,30,1)$. fa_b_c_e $(b 2, c 4, e 4,30,1)$. fa_b_c_e $(b 2, c 5, e 4,30,1)$. fa_b_c_e $(b 2, c 6, e 4,30,1)$. fa_b_c_e $(b 2, c 7, e 4,30,1)$. fa_b_c_e $(b 2, c 8, e 4,30,1)$. fa_b_c_e $(b 2, c 9, e 4,30,1)$. fa_b_c_e $(\mathrm{b} 2, \mathrm{~m} 10, e 4,30,1)$. fa_b_c_e $(\mathrm{b} 2, \mathrm{~m} 11, \mathrm{e} 4,30,1)$. fa_b_c_e (b2, m12, e4, 30, 1). fa_b_c_e (b2, m13, e4, 30, 1). fa_b_c_e $(\mathrm{b} 2, \mathrm{m14}, \mathrm{e} 4,30,1)$. fa_b_c_e $(\mathrm{b} 2, \mathrm{~m} 15, \mathrm{e} 4,30,1)$. fa_b_c_e $(b 3, c 1, e 4,30,1)$. fa_b_c_e $(b 3, c 2, e 4,30,1)$. fa_b_c_e $(b 3, c 3, e 4,30,1)$. fa_b_c_e $(\mathrm{b} 3, \mathrm{c} 4, \mathrm{e} 4,30,1)$. fa_b_c_e $(b 3, c 5, e 4,30,1)$. fa_b_c_e $(b 3, c 6, e 4,30,1)$. fa_b_c_e $(b 3, c 7, e 4,30,1)$. fa_b_c_e $(b 3, c 8, e 4,30,1)$. fa_b_c_e $(\mathrm{b} 3, \mathrm{c} 9, \mathrm{e} 4,30,1)$. fa_b_c_e $(\mathrm{b} 3, \mathrm{m1} 10, \mathrm{e} 4,30,1)$. fa_b_c_e $(\mathrm{b} 3, \mathrm{~m} 11, \mathrm{e} 4,30,1)$. fa_b_c_e $(\mathrm{b} 3, \mathrm{~m} 12, \mathrm{e} 4,30,1)$. fa_b_c_e (b3, m13,e4, 30, 1). fa_b_c_e (b3, m14, e4, 30, 1). fa_b_c_e $(\mathrm{b} 3, \mathrm{~m} 15, \mathrm{e} 4,30,1)$.fa_b_c_e $(\mathrm{b} 4, \mathrm{c} 1, \mathrm{e} 4,30,1)$. fa_b_c_e $(b 4, c 2, e 4,30,1)$. fa_b_c_e $(b 4, c 3, e 4,30,1)$. fa_b_c_e $(b 4, c 4, e 4,30,1)$. fa_b_c_e $(b 4, c 5, e 4,30,1)$. fa_b_c_e $(b 4, c 6, e 4,30,1)$. fa_b_c_e $(b 4, c 7, e 4,30,1)$. fa_b_c_e $(b 4, c 8, e 4,30,1)$. fa_b_c_e $(b 4, c 9, e 4,30,1)$. fa_b_c_e $(\mathrm{b} 4, \mathrm{~m} 10, e 4,30,1)$.fa_b_c_e $(\mathrm{b} 4, \mathrm{~m} 11, \mathrm{e} 4,30,1)$. fa_b_c_e $(\mathrm{b} 4, \mathrm{~m} 12, \mathrm{e} 4,30,1)$. fa_b_c_e $(\mathrm{b} 4, \mathrm{~m} 13, \mathrm{e} 4,30,1)$. fa_b_c_e (b4, m1 4, e4, 30,1). fa_b_c_e (b4, m15, e4, 30, 1). 
fa_b_c_e $(b 1, c 1, e 3,50,1)$. fa_b_c_e $(b 1, c 6, e 3,50,1)$. $\mathrm{fa} \mathrm{b}^{-} \mathrm{c} e(\mathrm{~b} 1, \mathrm{c} 7, \mathrm{e3}, 50,1)$. fa b $\mathrm{c}^{-} \mathrm{e}(\mathrm{b} 1, \mathrm{c} 8, \mathrm{e}, 50,1)$. $\mathrm{fa} b \mathrm{c} e(\mathrm{~b} 1, \mathrm{c} 9, \mathrm{e} 3,50,1)$. $\mathrm{fa} b \mathrm{c} e(\mathrm{~b} 2, \mathrm{c} 3, \mathrm{e} 3,50,1)$. fa_b_c_e (b2, c4,e3,50,1). fa_b_c_e (b2, m13,e3, 50, 1) $\mathrm{fa} b \mathrm{c} e(\mathrm{~b} 2, \mathrm{m1} 4, \mathrm{e} 3,50,1)$. fa $\mathrm{b} c \mathrm{c}(\mathrm{b} 3, \mathrm{c} 7, \mathrm{e} 3,50,1)$. fa_b_c_e (b3, c8,e3,50,1). fa_b_c_e (b3, m13,e3, 50,1).

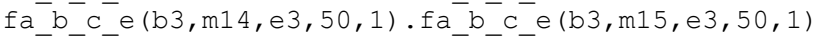
$\mathrm{fa} b \mathrm{c} e(\mathrm{~b} 4, \mathrm{c} 1, e 3,50,1)$. fa b c e (b4, c2,e3,50,1). $\mathrm{fa}{ }^{-} \mathrm{b}{ }^{-}{ }^{-} \mathrm{e}(\mathrm{b} 4, \mathrm{c} 3, \mathrm{e3}, 50,1)$. fa_b_c_e $(\mathrm{b} 4, \mathrm{c} 4, \mathrm{e} 3,50,1)$. $\mathrm{fa}{ }^{-} \mathrm{b}^{-} \mathrm{c}^{-} \mathrm{e}(\mathrm{b} 4, \mathrm{c} 5, \mathrm{e3}, 50,1)$. fa b ${ }^{-}{ }^{-} \mathrm{e}(\mathrm{b} 4, \mathrm{c} 9, \mathrm{e} 3,50,1)$. $\mathrm{fa} b \mathrm{c} e(\mathrm{~b} 4, \mathrm{m10}, \mathrm{e} 3,50,1)$. fa $\mathrm{b} c \mathrm{c}(\mathrm{b} 4, \mathrm{c} 3, \mathrm{e} 1,50,1)$. fa_b_c_e $(\mathrm{b} 4, \mathrm{c} 4, \mathrm{e} 1,50,1)$. fa_b_c_e $(\mathrm{b} 4, \mathrm{c} 5, \mathrm{e} 1,50,1)$. $\mathrm{fa} b \mathrm{c} e(\mathrm{~b} 4, \mathrm{c} 9, \mathrm{e} 1,50,1)$. $\mathrm{fa} \mathrm{b}^{-} \mathrm{c} e(\mathrm{~b} 4, \mathrm{~m} 10, \mathrm{e} 1,50,1)$. oOrders

$\operatorname{orders}(1, \mathrm{~d} 1, \mathrm{c} 1,30,2) . \operatorname{orders}(2, \mathrm{~d} 1, \mathrm{c} 2,30,2)$ $\operatorname{orders}(3, \mathrm{~d} 2, \mathrm{c} 3,30,2)$. $\operatorname{orders}(4, \mathrm{~d} 1, \mathrm{c} 4,30,2)$. $\operatorname{orders}(5, \mathrm{~d} 3, \mathrm{c} 5,30,2)$. $\operatorname{orders}(6, \mathrm{~d} 1, \mathrm{c} 6,30,2)$ $\operatorname{orders}(7, \mathrm{~d} 4, \mathrm{c} 7,30,2)$. $\operatorname{orders}(8, \mathrm{~d} 1, \mathrm{c} 8,30,2)$. $\operatorname{orders}(9, \mathrm{~d} 5, \mathrm{c} 9,30,2)$. $\operatorname{orders}(10, \mathrm{~d} 1, \mathrm{c} 10,30,2)$. $\operatorname{orders}(11, \mathrm{~d} 6, \mathrm{c} 1,30,2) . \operatorname{orders}(12, \mathrm{~d} 2, \mathrm{c} 2,30,2)$. $\operatorname{orders}(13, \mathrm{~d} 8, \mathrm{c} 3,30,2)$. $\operatorname{orders}(14, \mathrm{~d} 2, \mathrm{c} 4,30,2)$. $\operatorname{orders}(15, \mathrm{~d} 9, \mathrm{c} 5,30,2)$. $\operatorname{orders}(16, \mathrm{~d} 2, \mathrm{c} 6,30,2)$. $\operatorname{orders}(17, \mathrm{~d} 10, \mathrm{c} 7,30,2) . \operatorname{orders}(18, \mathrm{~d} 2, \mathrm{c} 8,30,2)$. $\operatorname{orders}(19, d 2, c 9,30,2)$. $\operatorname{orders}(20, d 2, c 10,30,2)$. $\operatorname{orders}(21, d 3, c 1,30,2) . \operatorname{orders}(22, d 3, c 2,30,2)$. $\operatorname{orders}(23, \mathrm{~d} 3, \mathrm{c} 3,30,2) . \operatorname{orders}(24, \mathrm{~d} 3, \mathrm{c} 4,30,2)$. $\operatorname{orders}(25, d 3, c 5,30,2)$. orders $(26, d 3, c 6,30,2)$. $\operatorname{orders}(27, d 3, c 7,30,2)$. orders $(28, d 3, c 8,30,2)$. $\operatorname{orders}(29, \mathrm{~d} 3, \mathrm{c} 9,30,2)$. $\operatorname{orders}(30, \mathrm{~d} 3, \mathrm{c} 10,30,2)$. $\operatorname{orders}(41, \mathrm{~d} 4, \mathrm{c} 1,30,2)$. orders $(42, \mathrm{~d} 4, \mathrm{c} 2,30,2)$ $\operatorname{orders}(43, \mathrm{~d} 4, \mathrm{c} 3,30,2) . \operatorname{orders}(44, \mathrm{~d} 4, \mathrm{c} 4,30,2)$. $\operatorname{orders}(45, \mathrm{~d} 4, \mathrm{c} 5,30,2) . \operatorname{orders}(46, \mathrm{~d} 4, \mathrm{c} 6,30,2)$ $\operatorname{orders}(47, \mathrm{~d} 4, \mathrm{c} 7,30,2) . \operatorname{orders}(48, \mathrm{~d} 4, \mathrm{c} 8,30,2)$. $\operatorname{orders}(49, \mathrm{~d} 4, \mathrm{c} 9,30,2)$. orders $(50, \mathrm{~d} 10, \mathrm{~m} 10,30,2)$. $\operatorname{orders}(51, \mathrm{~d} 5, \mathrm{c} 1,30,2) . \operatorname{orders}(52, \mathrm{~d} 11, \mathrm{c} 2,30,2)$. $\operatorname{orders}(53, \mathrm{~d} 5, \mathrm{c} 3,30,2) . \operatorname{orders}(54, \mathrm{~d} 12, \mathrm{c} 4,30,2)$. $\operatorname{orders}(55, \mathrm{~d} 5, \mathrm{c} 5,30,2) . \operatorname{orders}(56, \mathrm{~d} 13, \mathrm{c} 6,30,2)$. $\operatorname{orders}(57, \mathrm{~d} 5, \mathrm{c} 7,30,2)$. orders $(58, \mathrm{~d} 14, \mathrm{c} 8,30,2)$. $\operatorname{orders}(59, \mathrm{~d} 5, \mathrm{c} 9,30,2)$. orders $(60, \mathrm{~d} 15, \mathrm{c} 10,30,2)$.

\section{REFERENCES}

[1] K. Burgess, P. J. Singh, R. Koroglu, "Supply chain management: a structured literature review and implications for future research", in: International Journal of Operations \& Production Management, Vol. 26 Issue: 7 , pp.703 - 729, 2006.

[2] K. C. Tan, "A framework of supply chain management literature", in: European Journal of Purchasing \& Supply Management, 7, pp 39-48, 2001.

[3] G.Q. Huang, J.S.K. Lau, K.L. Mak, "The impacts of sharing production information on supply chain dynamics: a review of the literature", in: International Journal of Production Research, 41, pp. 1483-1517, 2003.

[4] J. Mula, D. Peidro, M. Diaz-Madronero, E. Vicens, "Mathematical programming models for supply chain production and transport planning", in: European Journal of Operational Research, 204, pp. 377-390, 2010.

[5] K. Apt, M. Wallace, "Constraint Logic Programming using Eclipse". Cambridge: Cambridge University Press, 2006.
[6] F. Rossi, P. Van Beek, T. Walsh, "Handbook of Constraint Programming”, New York: Elsevier Sc. Inc, 2006.

[7] P. Sitek J. Wikarek, "A hybrid method for modeling and solving constrained search problems", in: Federated Conference on Computer Science and Information Systems (FedCSIS 2013), pp. 385-392, 2013.

[8] P. Sitek, J. Wikarek, "A Hybrid Programming Framework for Modeling and Solving Constraint Satisfaction and Optimization Problems", in: Scientific Programming, vol. 2016, Article ID 5102616, 2016. doi:10.1155/2016/5102616.

[9] P. Sitek, P., J. Wikarek, "A Hybrid Approach to the Optimization of Multiechelon Systems“, in: Mathematical Problems in Engineering vol. 2015, Article ID 925675, 2015. doi:10.1155/2015/925675.

[10] P. Sitek, "A hybrid approach to the two-echelon capacitated vehicle routing problem (2E-CVRP) “, in: Advances in Intelligent Systems and Computing, 267, pp.251-263, 2014. doi:10.1007/978-3-319. 05353-0_25.

[11] A. Schrijver, "Theory of Linear and Integer Programming”, John Wiley \& Sons, New York, NY, USA, 1998.

[12] Eclipse, 2015, Eclipse - The Eclipse Foundation open source community website, Accessed August 12, www.eclipse.org

[13] G.M. Thompson, "Optimizing restaurant table configuration: Specifying combinable tables", in: Cornell Hotel and Restaurant Administration Quartely, 44, pp. 53-60, 2003.

[14] M. Milano, M. Wallace, "Integrating Operations Research in Constraint Programming”, in: Annals of Operations Research, 175(1), pp. $37-76,2010$

[15] T. Achterberg, T. Berthold, T. Koch, K. Wolter, "Constraint Integer Programming. A New Approach to Integrate CP and MIP”, in: Lecture Notes in Computer Science, 5015, pp. 6-20, 2008.

[16] A. Bockmayr, T. Kasper, "Branch-and-Infer, A Framework for Combining CP and IP”, in: Constraint and Integer Programming Operations Research/Computer Science Interfaces Series, 27, pp. 5987, 2004.

[17] J. Wikarek, "A Novel Approach to Optimization of Jobs in Groups", in: Progress in Automation, Robotics and Measuring Techniques, pp. 313-322, 2015. doi:10.1007/978-3-319-15796-2_32.

[18] S. Bak, R. Czarnecki, S. Deniziak "Synthesis of Real-Time Cloud Applications for Internet of Things", in: Turkish Journal of Electrical Engineering \&Computer Sciences, 2013. doi: 10.3906/elk-1302-178.

19] M. Relich, A. Swic, A. Gola, "A Knowledge-Based Approach to Product Concept Screening", in: Omatu, S. (eds.) Advances in Intelligent Systems and Computing, vol. 373, pp. 341-348, 2015.

[20] K. Grzybowska, "Selected Activity Coordination Mechanisms in Complex Systems, Highlights of Practical Applications of Agents, Multi-Agent Systems, and Sustainability", in: The PAAMS Collection Communications in Computer and Information Science, Volume 524, J. Bajo et al. (Eds.), Springer International Publishing Switzerland, pp. 69-79, 2015. DOI: 10.1007/978-3-319-19033-4 6 .

[21] P. Nielsen, I. Nielsen, K. Steger-Jensen, "Analyzing and evaluating product demand interdependencies", in: Computers in Industry, 61 (9), pp. 869-876, 2010. doi:10.1016/j.compind.2010.07.012.

[22] D. Krenczyk, J. Jagodzinski, "ERP, APS and Simulation Systems Integration to Support Production Planning and Scheduling", in: Advances in Intelligent Systems and Computing, Vol. 368, Springer International Publishing, pp 451-46, 2015.

[23] S. Deniziak, T. Michno, "Query by Shape for Image Retrieval from Multimedia Databases", in: Communications in Computer and Information Science, Springer, 521, pp. 377-386, 2015. doi: 10.1007/978-3-319-18422-7_33 